\title{
TOKSISITAS EKSTRAK BIJI JARAK PAGAR (Jatropha curcas L.) TERHADAP ULAT KROP KUBIS (Crocidolomia pavonana F.)
}

\author{
Rully Pebriansyah, Nur Yasin, Subeki \& Hamim Sudarsono \\ Jurusan Agroteknologi, Fakultas Pertanian Universitas Lampung, \\ Jl. Prof. SoemantriBrodjonegoro, No. 1, Bandar Lampung 35145 \\ Email: rully260292@gmail.com
}

\begin{abstract}
ABSTRAK
Penggunaan insektisida sintetis banyak digunakan petani dalam mengatasi serangan hama Crocidolomia pavonana pada tanaman kubis. Namun demikian, penggunakan insektisida ini dapat menyebabkan resistensi, resurjensi, terbunuhnya musuh alami, pencemaran lingkungan, dan membahayakan kesehatan manusia. Oleh karena itu, dibutuhkan alternatif lain untuk mengendalikan hama C. pavonana yaitu dengan insektisida nabati dari biji jarak pagar (Jatropha curcas L.). Penelitian ini bertujuan untuk mengetahui aktivitas ekstrak biji jarak pagar terhadap mortalitas ulat krop kubis $C$. pavonana dan tingkat konsentrasi ekstrak biji jarak pagar yang dapat menyebabkan mortalitas ulat krop kubis $C$. pavonana. Penelitian ini terdiri dari dua tahap, yaitu fraksinasi ektrak biji jarak pagar untuk menentukan fraksi aktif yang dapat mematikan ulat $C$. pavonana (bioassay I) dan pengujian fraksi aktif pada konsentrasi kontrol, 78, 156, 312, 625, 1.250, 2.500, 5.000, 10.000, dan $20.000 \mathrm{ppm}$ terhadap mortalitas ulat $C$. pavonana (bioassay II). Hasil penelitian menunjukkan bahwa ekstrak biji jarak pagar fraksi $100 \%$ $\mathrm{CHCl}_{3}$ konsentrasi 20.000 ppm pada 24 jsa menyebabkan mortalitas ulat $C$. pavonana sebesar $100 \%$ lebih tinggi daripada fraksi $3 \% \mathrm{MeOH} / \mathrm{CHCl}_{3}, 20 \% \mathrm{MeOH} / \mathrm{CHCl}_{3}$, dan $\mathrm{MeOH}$. Ekstrak biji jarak pagar fraksi 100\% $\mathrm{CHCl}_{3}$ konsentrasi $10.000 \mathrm{ppm}$ pada 96 jsa menyebabkan mortalitas ulat C. pavonana lebih dari $50 \%$.
\end{abstract}

Kata kunci: Crocidolomia pavonana, jarak pagar, Jatropha curcas, mortalitas, toksisitas

\section{PENDAHULUAN}

Tanaman kubis (Brassica oleracea L.) merupakan sayuran dataran tinggi yang banyak dibudidayakan di Indonesia. Namun dalam usaha produksi tanaman kubis seringkali dihadapkan pada adanya gangguan hama dan pathogen. Salah satu jenis hama yang dapat mengganggu budidaya tanama kubis adalah ulat krop kubis, Crocidolomia pavonana (F.) (sin. C. binotalis Zeller) (Lepidoptera: Pyralidae) ) (Uhan, 1993). Serangan C. pavonana dapat menyebabkan kehilangan hasil $100 \%$, apabila tanaman tidak diberi perlakuan insektisida (Permadi dan Sastrosiswojo, 1993).

Penggunaan insektisida sintetis banyak digunakan petani dalam mengatasi serangan ulat $C$. pavonana. Namun dalam penggunaannya, insektisida ini dapat menimbulkan resistensi, resurjensi, terbunuhnya musuh alami, pencemaran lingkungan, dan membahayakan kesehatan manusia (Kardinan, 2001). Dengan demikian, dibutuhkan alternatif lain untuk mengendalikan serangan ulat $C$. pavonana. Salah satu diantaranya adalah dengan menggunakan insektisida nabati. Insektisida nabati tersebut salah satunya adalah biji jarak pagar.
Biji jarak pagar mengandung senyawa racun phorbolester dan cursin yang bersifat sangat toksik dalam mematikan sel hidup (Wina et al., 2008). Senyawa phorbolester dapat menghambat enzim protein kinase yang berperan dalam pertumbuhan sel dan jaringan (Aitken, 1986 dalam Evans, 1986). Sedangkan senyawa cursin dapat menghambat penyerapan nutrien dan mengurangi nitrogen endogenous sel (Fasina et al., 2004 dalam Wina et al., 2008).

Hasil penelitian sebelumnya menunjukkan bahwa biji jarak pagar konsentrasi $10 \mathrm{~mL} / \mathrm{L}$ dengan penambahan detergen $1 \mathrm{~g} / \mathrm{L}$ dapat menyebabkan mortalitas larva Achaea janata sebesar $85,34 \%$ (Tukimin et al., 2010). Biji jarak pagar dapat membunuh telur Callosobruchus maculates (Adebowale dan Adedire, 2006). Berdasarkan hal tersebut ekstrak biji jarak pagar yang bersifat toksik terhadap serangga, maka besar kemungkinan ekstrak biji jarak pagar juga dapat digunakan untuk mengendalikan ulat $C$. pavonana pada tanaman kubis. Oleh karena itu, pada penelitian ini dilakukan pengujian toksisitas fraksi biji jarak pagar pada berbagai konsentrasi terhadap mortalitas ulat krop kubis $C$. pavonana. 
Penelitian ini bertujuan untuk mengetahui pengaruh aktivitas ekstrak biji jarak pagar terhadap mortalitas ulat krop kubis Crocidolomia pavonana $\mathrm{F}$. dan untuk mengetahui tingkat konsentrasi ekstrak biji jarak pagar yang dapat menyebabkan mortalitas ulat krop kubis Crocidolomia pavonana $\mathrm{F}$.

\section{BAHAN DAN METODE}

Penelitian ini dilaksanakan pada bulan Juli sampai Oktober 2015. Penelitian ini dilaksanakan di Laboratorium Pengujian Mutu Hasil Pertanian Jurusan Teknologi Hasil Pertanian (THP) serta Laboratorium Hama dan Penyakit Tanaman Jurusan Agroteknologi (AGT), Fakultas Pertanian, Universitas Lampung.

Bahan-bahan yang digunakan dalam penelitian ini yaitu biji jarak pagar yang diperoleh dari Kecamatan Bengkunat, Lampung Barat, kapas, larva biakan Crocidolomia pavonana instar II, daun brokoli, tanah, pupuk kandang, air, EtOH, EtOAc, heksan $\mathrm{CHCl}_{3}$ untuk analisis. Alat yang digunakan adalah penyaring, pinset, alat tulis, plastik, toples, cawan petri, tali karet, polibeg, timbangan, kain kasa, gelas ukur, kain saring, labu evaporator, corong pemisah, mikro pipet, Kolom chromatography, rotary evaporator, baker glass, dan Erlenmeyer.

Percobaan ini disusun dalam Rancangan Acak Kelompok Lengkap (RAKL). Bioassay I dilakukan dengan 4 pelakuan yaitu fraksi $\mathrm{CHCl}_{3}, 3 \% \mathrm{MeOH} /$ $\mathrm{CHCl}_{3}, 20 \% \mathrm{MeOH} / \mathrm{CHCl}_{3}$, dan $\mathrm{MeOH}$ dengan 4 ulangan menggunakan konsentrasi $20.000 \mathrm{ppm}$. Bioassay II dengan 10 perlakuan konsentrasi yaitu 0 (kontrol), 78, 156, 312, 625, 1.250, 2.500, 5.000, 10.000, dan 20.000 ppm dengan 4 ulangan. Setiap satuan ulangan percobaan menggunakan 20 ekor larva $C$. pavonana instar II dan daun brokoli sebagai pakan.

Data yang diperoleh adalah data mortalitas ulat C. pavonana yang kemudian dianalisis dengan sidik ragam untuk mendapatkan penduga ragam galat. Uji lanjut dilakukan dengan uji Beda Nyata Terkecil (BNT) pada taraf nyata $1 \%$ atau $5 \%$. Untuk mengetahui toksisitas ekstrak biji jarak pagar dianalisis menggunakan $\mathrm{LC}_{50}$ yang dihitung menggunakan analisis probit dengan program micro probit 3.0. Berikut ini adalah tahapan penelitian yang dilaksanakan:

(1). Penyediaan pakan serangga uji

Daun tanaman brokoli digunakan sebagai pakan dalam perbanyakan serangga uji dan digunakan pada saat aplikasi.

(2). Perbanyakan Serangga Uji

Perbanyakan dimulai dengan memindahkan ulat yang didapat di lapangan ke dalam toples. Pada ulat instar 1-3 toples hanya diberi daun brokoli sebagai pakan, dan mulai dari istar 4 toples diberi daun brokoli dan tanah kering. Tanah kering ini digunakan ulat untuk menyembunyikan diri dan berubah menjadi pupa, kemudian toples ditutup dengan kain. Ulat akan menjadi pupa, lalu pupa akan berubah menjadi imago. Imago dipindahkan ke dalam kurungan dan diberi tanaman brokoli untuk tempat meletakkan telur. Setelah berada di dalam kurungan, imago menghasilkan telur yang diletakkan di bawah permukaan daun. Daun yang ada telurnya dipetik dan diletakkan ke dalam toples. Setelah telur menetas, larva dirawat sampai menjadi instar II untuk digunakan sebagai bahan uji pada bioassay I dan bioassay II.

(3). Ekstrak Biji Jarak Pagar

Buah jarak pagar kering yang berasal dari Kecamatan Bengkunat, Lampung Barat dipisahkan antara kulit buah dan bijinya. Setelah itu, biji jarak pagar ditumbuk hingga menjadi tepung. Tepung biji jarak pagar $3 \mathrm{~kg}$ direndam dengan menggunakan heksan $9 \mathrm{~L}$ selama 2 minggu dan kemudian disaring. Dari perendaman ini dihasilkan filtrat $9 \mathrm{~L}$ dan ampas biji jarak pagar $3 \mathrm{~kg}$. Ampas biji jarak pagar $(3 \mathrm{~kg}$ ) direndam dalam $15 \mathrm{LEtOH}$ $70 \%$ dan dibiarkan selama 14 hari, lalu dilakukan penyaringan. Dari penyaringan ini dihasilkan residu 3 $\mathrm{kg}$ dan filtrat sebanyak 14 L. Filtrat yang dihasilkan (14 L) kemudian dievaporasi hingga menghasilkan konsentrat $1 \mathrm{~L}$ dan diekstrak dengan EtOAc $(1 \mathrm{~L}$ x $4 \mathrm{~L})$ dan menghasilkan lapisan air sebanyak $1 \mathrm{~L}$ dan lapisan EtOAc sebanyak 4 L. Lapisan EtOAc dievaporasi hingga diperoleh padatan lalu dimasukkan ke dalam $\mathrm{SiO} 2$ kolom kromatografi dan dielusi dengan $\mathrm{CHCl}_{3}(1 \mathrm{~L}), 3 \%$ $\mathrm{MeOH} / \mathrm{CHCl}_{3}(1 \mathrm{~L}), 20 \% \mathrm{MeOH} / \mathrm{CHCl}_{3}(1 \mathrm{~L})$, dan $\mathrm{MeOH}(1 \mathrm{~L})$ secara berurutan.

Fraksi yang diperoleh dari kolom kromatografi $\mathrm{SiO}_{2}$ dilakukan uji bioassay I untuk mengetahui fraksi mana yang aktif dalam mematikan C. pavonana. Setelah didapatkan fraksi yang aktif, selanjutkan dilakukan uji bioassay II, dengan konsentrasi 0 (kontrol), $78,156,625,1.250,2.500,5.000,10.000$, dan 20.000 ppm.

\section{(4). Pengamatan}

Pengamatan dilakukan untuk mengetahui persentase mortalitas $C$. pavonana. Penghitungan jumlah mortalitas serangga yang diamati pada 24,48 , 72, 96, 120, 144 (jsa) sampai $C$. pavonana mati atau sampai instar 5. Persentase mortalitas serangga dihitung menggunakan rumus:

$$
\mathrm{M}(\%)=\frac{\mathrm{x}}{\mathrm{y}} \times 100
$$


Keterangan :

$X=$ jumlah serangga yang mati

$\mathrm{Y}=$ jumlah serangga uji

Menurut Hasibuan (2003), sebelum melakukan perhitungan faktor kematian (faktor kematian pada kontrol yang disebabkan oleh factor lain) harus terlebih dahulu dikoreksi dengan rumus Abbot (1925), yaitu:

Keterangan :

$$
\mathrm{M}(\%)=\frac{\mathrm{x}-\mathrm{y}}{100-\mathrm{y}} \times 100
$$

$\mathrm{M}=$ Mortaliatas

$\mathrm{X}=$ Persentase serangga uji yang mati pada perlakuan $\mathrm{Y}=$ Persentase serangga uji yang mati pada kontro

\section{Lethal Concentration $\left(\mathrm{LC}_{50}\right)$}

Toksisitas ekstrak biji jarak pagar dianalisis dengan menggunakan Lethal Concentration $\left(\mathrm{LC}_{50}\right)$ yang dihitung menggunakan analisis probit dengan program micro probit 3.0. $\mathrm{LC}_{50}$ dihitung mulai dari kematian awal setiap unit percobaan (Sparks and Sparks, 1989, dalam Carrillo et al., 1994)

\section{Lethal Time $\left(\mathrm{LT}_{50}\right)$}

Toksisitas ekstrak biji jarak pagar dianalisis dengan menggunakan Lethal Time $\left(\mathrm{LT}_{50}\right)$ yang dihitung menggunakan analisis probit dengan program micro probit 3.0. $\mathrm{LT}_{50}$ dihitung mulai dari kematian awal setiap unit percobaan (Sparks and Sparks, 1989, dalam Carrillo et al., 1994)

\section{HASIL DAN PEMBAHASAN}

\section{Ekstrak Biji Jarak Pagar}

Fraksinasi biji jarak pagar diawali dengan perendaman dalam larutan heksan untuk menghilangkan fraksi minyak yang terkandung dalam bahan. Selanjutnya biji jarak pagar diekstraksi dengan etanol $(\mathrm{EtOH})$ hingga diperoleh filtrat dan ampas. Filtrat kemudian diekstrak dengan etil asetat (EtOAc) hingga diperoleh lapisan air $\left(\mathrm{H}_{2} \mathrm{O}\right)$ dan lapisan EtOAc dengan rendemen masingmasing sebesar $22.73 \%$ dan $15.27 \%$ (Tabel 1). Lapisan EtOAc selanjutnya dilakukan kolom kromatografi hingga diperoleh fraksi $\mathrm{CHCl}_{3}, 3 \% \mathrm{MeOH} / \mathrm{CHCl}_{3}, 20 \%$ $\mathrm{MeOH} / \mathrm{CHCl}_{3}$, dan $\mathrm{MeOH}$ dengan rendemen secara berurutan sebesar $9.87 \%, 32 \%, 0.27 \%$, dan $0.27 \%$ (Tabel 1). Hasil evaporasi fraksi $\mathrm{CHCl}_{3}$ mempunyai karakteristik kental berminyak berwarna coklat kekuningan, fraksi $3 \% \mathrm{MeOH} / \mathrm{CHCl}_{3}$ kental berwarna coklat kekuningan. Fraksi $20 \% \mathrm{MeOH} / \mathrm{CHCl}_{3}$ serbuk berwarna coklat kekuningan, dan fraksi $\mathrm{MeOH}$ serbuk berwarna coklat kekuningan.
Mortalitas Ulat Crocidolomia pavonana

Pengujian terhadap mortalitas ulat Crocidolomia pavonana dilakukan bioassay I dan II. Pengujian dilakukan pada daun brokoli yang mengandung fraksi uji dan diberikan pada ulat C. pavonana instar II.

\section{Bioassay I}

Fraksinasi lapisan etil asetat (EtOAc) pada silica gel kolom kromatografi menghasilkan fraksi $100 \%$ $\mathrm{CHCl}_{3}, 3 \% \mathrm{MeOH} / \mathrm{CHCl}_{3}, 20 \% \mathrm{MeOH} / \mathrm{CHCl}_{3}$, dan $100 \% \mathrm{MeOH}$. Masing-masing fraksi selanjutnya diuji bioassay I dengan cara daun brokoli direndam dalam fraksi uji pada konsentrasi 20.000 ppm dan diberikan pada ulat $C$. pavonana. Persentase mortalitas $C$. pavonana pada berbagai fraksi dapat dilihat pada Tabel 2. Tabel 2 menunjukkan bahwa beberapa fraksi ekstrak biji jarak pagar pada 24 jsa sudah memberikan pengaruh terhadap mortalitas ulat $C$. pavonana walaupun masih rendah. Fraksi $100 \% \mathrm{CHCl}_{3}$ pada 24 jsa menunjukkan mortalitas tertinggi yaitu $100 \%$ berbeda nyata dengan fraksi 3\% MeOH/ $\mathrm{CHCl}_{3} 20 \% \mathrm{MeOH} / \mathrm{CHCl}_{3}$ dan $100 \%$ $\mathrm{MeOH}$. Fraksi 3\% $\mathrm{MeOH} / \mathrm{CHCl}_{3}, 20 \% \mathrm{MeOH} / \mathrm{CHCl}_{3}$ dan $100 \% \mathrm{MeOH}$ menunjukkan mortalitas ulat $C$. pavonana secara berurutan sebesar $8,75 \%, 0 \%$, dan $1,25 \%$.

Hingga pada akhir waktu pengamatan 144 jsa bahwa fraksi $100 \% \mathrm{CHCl}_{3}$ menunjukkan mortalitas tertinggi yaitu sebesar $100 \%$ berbeda nyata dengan fraksi $3 \% \mathrm{MeOH} / \mathrm{CHCl}_{3}$ 20\% $\mathrm{MeOH} / \mathrm{CHCl}_{3}$ dan $100 \%$ $\mathrm{MeOH}$. Fraksi $3 \% \mathrm{MeOH} / \mathrm{CHCl}_{3}, 20 \% \mathrm{MeOH} / \mathrm{CHCl}_{3}$ dan $100 \% \mathrm{MeOH}$ menunjukkan mortalitas ulat $C$. pavonana secara berurutan sebesar 18,75\%, 12,50\%, dan $16,25 \%$. Selama waktu pengamatan fraksi $100 \%$ $\mathrm{CHCl}_{3}$ menunjukkan mortalitas lebih tinggi dibadingkan dengan fraksi lainnya. Oleh karena itu fraksi 100\% $\mathrm{CHCl}_{3}$ perlu dilakukan penelitian lebih lanjut pada bioassay II untuk mengetahui dosis efektif yang dapat mematikan ulat C. pavonana .

\section{Bioassay II}

Hasil bioassay I menunjukkan bahwa fraksi $100 \%$ $\mathrm{CHCl}_{3}$ lebih aktif daripada fraksi $3 \% \mathrm{MeOH} / \mathrm{CHCl}_{3}$,

Tabel 1. Rendemen berbagai fraksi biji jarak pagar

\begin{tabular}{clc}
\hline No & \multicolumn{1}{c}{ Fraksi } & Rendemen $(\%)$ \\
\hline 1 & $\mathrm{H}_{2} \mathrm{O}$ & 22,73 \\
2 & $\mathrm{EtOAc}$ & 15,27 \\
3 & $\mathrm{CHCl}_{3}$ & 9,87 \\
4 & $3 \% \mathrm{MeOH} / \mathrm{CHCl}_{3}$ & 3,20 \\
5 & $20 \% \mathrm{MeOH} / \mathrm{CHCl}_{3}$ & 0,27 \\
6 & $\mathrm{MeOH}$ & 0,27 \\
\hline
\end{tabular}


$20 \% \mathrm{MeOH} / \mathrm{CHCl}_{3}$ dan $100 \% \mathrm{MeOH}$. Oleh karena itu, fraksi $100 \% \mathrm{CHCl}_{3}$ diaplikasikan pada ulat $C$. pavonana pada konsentrasi $0,78,156,312,625,1.250$, $2.500,5.000,10.000$, dan 20.000 ppm. Persentase mortalitas $C$. pavonana pada berbagai konsentrasi fraksi $100 \% \mathrm{CHCl}_{3}$ dapat dilihat pada Tabel 3. Hasil bioassay II menunjukkan bahwa persentase mortalitas ulat C. Pavonana pada fraksi $100 \% \mathrm{CHCl}_{3}$ konsentrasi 20.000 ppm pada 48 jsa menunjukkan mortalitas ulat $C$. pavonana mencapai $100 \%$ berbeda nyata dengan konsentrasi dibawahnya. Sedangkan konsentrasi10.000 ppm fraksi $100 \% \mathrm{CHCl}_{3}$ pada 96, 120, dan 144 jsa menunjukkan mortalitas secara berurutan sebesar $57,50 \%, 70 \%$, dan $73 \%$ berbeda nyata dengan konsentrasi lainnya. Hal ini menunjukkan bahwa fraksi $100 \% \mathrm{CHCl}_{3}$ untuk konsentrasi 10.000 ppm pada waktu 96, 120, dan 144 jsa menunjukkan bahwa biji jarak pagar bersifat toksik dalam mengendalikan ulat $C$. pavonana dan tidak merusak daun brokoli yang diaplikasi pestisida nabati tersebut.

Sayuthi et al. (2014) menyebutkan bahwa fraksi biji jarak pagar konsentrasi $60 \mathrm{~mL} / \mathrm{L}$ pada 120 jsa menyebabkan mortalitas ulat $C$. pavonana sebesar 46,67\%. menurut Kodjo et al. (2011) bahwa ekstrak

Tabel 2. Persentase mortalitas ulat Crocidolomia pavonana instar II pada berbagai fraksi biji jarak pagar konsentrasi $20.000 \mathrm{ppm}$

\begin{tabular}{|c|c|c|c|c|c|c|}
\hline \multirow{2}{*}{$\begin{array}{l}\text { Waktu } \\
\text { (jsa) }\end{array}$} & \multicolumn{5}{|c|}{ Fraksi } & \multirow{2}{*}{ BNT } \\
\hline & Kontrol & $100 \% \mathrm{CHCl}_{3}$ & $3 \% \mathrm{MeOH} / \mathrm{CHCl}_{3}$ & $20 \% \mathrm{MeOH} / \mathrm{CHCl}_{3}$ & $100 \% \mathrm{MeOH}$ & \\
\hline & & &..$\%$ & .............. & $\ldots \ldots \ldots \ldots$ & \\
\hline 24 & $0 \mathrm{c}$ & $100 \mathrm{a}$ & $8,75 \mathrm{~b}$ & $0 \mathrm{c}$ & $1,25 \mathrm{c}$ & 6,41 \\
\hline 48 & $0 \mathrm{c}$ & $100 \mathrm{a}$ & $13,74 \mathrm{~b}$ & $3,75 \mathrm{c}$ & $6,25 c$ & 6,93 \\
\hline 72 & $0 \mathrm{c}$ & $100 \mathrm{a}$ & $16,25 \mathrm{~b}$ & $10 \mathrm{~b}$ & $11,25 \mathrm{~b}$ & 7,61 \\
\hline 96 & $0 \mathrm{c}$ & $100 \mathrm{a}$ & $18,75 \mathrm{~b}$ & $11,25 \mathrm{~b}$ & $15 \mathrm{~b}$ & 7,92 \\
\hline 120 & $0 \mathrm{c}$ & $100 \mathrm{a}$ & $18,75 \mathrm{~b}$ & $11,25 \mathrm{~b}$ & $16,25 \mathrm{~b}$ & 7,61 \\
\hline 144 & $0 \mathrm{c}$ & $100 \mathrm{a}$ & $18,75 \mathrm{~b}$ & $12,50 \mathrm{~b}$ & $16,25 \mathrm{~b}$ & 7,14 \\
\hline
\end{tabular}

Keterangan: Nilai dalam baris yang diikuti huruf yang sama menunjukkan tidak berbeda nyata pada uji BNT taraf nyata $5 \%$

Tabel 3. Persentase mortalitas ulat Crocidolomia pavonana instar II pada berbagai konsentrasi fraksi $100 \%$ $\mathrm{CHCL}_{3}$

\begin{tabular}{|c|c|c|c|c|c|c|c|c|c|c|c|}
\hline \multirow{2}{*}{$\begin{array}{c}\text { Waktu } \\
\text { (jsa) }\end{array}$} & \multicolumn{10}{|c|}{ Mortalitas pada konsentrasi (ppm) } & \multirow{2}{*}{ BNT } \\
\hline & 0 & 78 & 156 & 312 & 625 & 1.250 & 2.500 & 5.000 & 10.000 & 20.000 & \\
\hline \multicolumn{12}{|c|}{$\% \ldots$} \\
\hline \multirow[t]{2}{*}{24} & 0,00 & 0,00 & 0,00 & 2,50 & 1,25 & 7,50 & 11,25 & 16,25 & 22,50 & 97,50 & 9,13 \\
\hline & $\mathrm{e}$ & $\mathrm{e}$ & $\mathrm{e}$ & de & $\mathrm{e}$ & cde & $\mathrm{cd}$ & $\mathrm{bc}$ & $\mathrm{b}$ & a & \\
\hline \multirow[t]{2}{*}{48} & 0,00 & 0,00 & 1,25 & 3,75 & 3,75 & 12,50 & 18,75 & 21,25 & 30,00 & 100,00 & 8,15 \\
\hline & $\mathrm{e}$ & e & $\mathrm{e}$ & $\mathrm{e}$ & e & d & $\mathrm{cd}$ & c & b & a & \\
\hline \multirow[t]{2}{*}{72} & 0,00 & 0,00 & 1,25 & 6,25 & 6,25 & 18,75 & 23,75 & 25,00 & 46,25 & 100,00 & 7,23 \\
\hline & $\mathrm{d}$ & $\mathrm{d}$ & $\mathrm{d}$ & $\mathrm{d}$ & $\mathrm{d}$ & $\mathrm{c}$ & $\mathrm{c}$ & $\mathrm{c}$ & b & $\mathrm{a}$ & \\
\hline \multirow[t]{2}{*}{96} & 0,00 & 0,00 & 2,50 & 6,25 & 6,25 & 21,25 & 26,25 & 28,75 & 57,50 & 100,00 & 7,81 \\
\hline & $\mathrm{d}$ & $\mathrm{d}$ & $\mathrm{d}$ & $\mathrm{d}$ & $\mathrm{d}$ & $\mathrm{c}$ & $\mathrm{c}$ & $\mathrm{c}$ & b & $\mathrm{a}$ & \\
\hline \multirow[t]{2}{*}{120} & 0,00 & 1,25 & 2,50 & 8,75 & 11,25 & 28,75 & 42,50 & 53,75 & 70,00 & 100,00 & 7,63 \\
\hline & $\mathrm{h}$ & gh & $\mathrm{gh}$ & fg & $\mathrm{f}$ & $\mathrm{e}$ & d & $\mathrm{c}$ & b & $\mathrm{a}$ & \\
\hline \multirow[t]{2}{*}{144} & 0,00 & 2,50 & 3,75 & 10,00 & 12,50 & 30,00 & 43,75 & 55,00 & 73,75 & 100,00 & 7,25 \\
\hline & $\mathrm{h}$ & $\mathrm{h}$ & gh & fg & f & $\mathrm{e}$ & $\mathrm{d}$ & $\mathrm{c}$ & b & $\mathrm{a}$ & \\
\hline
\end{tabular}

Keterangan: Nilai dalam baris yang diikuti huruf yang sama menunjukkan tidak berbeda nyata pada uji BNT taraf nyata $5 \%$ 
biji jarak pagar dengan konsentrasi $20 \%$ dapat mematikan ulat instar III Plutella xylostela sebesar $58,98 \%$, sedangkan pada konsentrasi $10 \%$ dapat mematikan ulat C. pavonana instar II sebesar $80 \%$ (Arvina 2013 dalam Sayuthi et al., 2014).

\section{Lethal Concentration $\left(\mathrm{LC}_{50}\right)$}

Hasil penelitian menunjukkan bahwa fraksi ekstrak biji jarak pagar bersifat toksik terhadap ulat $C$. pavonana. Lethal concentration $\left(\mathrm{LC}_{50}\right)$ ekstrak biji jarak pagar dapat dilihat pada Tabel 4.Tabel 4 menunjukkan bahwa ekstrak biji jarak pagar memberikan lethal concentrasi $\left(\mathrm{LC}_{50}\right)$ terhadap $C$. pavonana pada $24,48,72,96,120$, dan 144 jsa secara berurutan sebesar 29.913, 20.843, 11.132, 8.026, 2.639, dan $2.490 \mathrm{ppm}$. Hal tersebut menunjukkan bahwa ekstrak biji jarak pagar memiliki potensi sebagai insektisida nabati pada jsa dan konsentrasi tertentu.

\section{Lethal Time $\left(\mathrm{LT}_{50}\right)$}

Hasil penelitian menunjukkan bahwa ekstrak biji jarak pagar bersifat toksik terhadap mortalitas ulat $C$. pavonana. Lethal Time $\left(\mathrm{LT}_{50}\right)$ ekstrak biji jarak pagar dapat dilihat pada Tabel 5. Tabel 5 menunjukkan bahwa lethal time $\left(\mathrm{LT}_{50}\right)$ ekstrak biji jarak pagar terhadap ulat C. pavonana pada konsentrasi 625, 1.250, 2.500, 5.000, dan $10.000 \mathrm{ppm}$ menunjukkan nilai $\mathrm{LT}_{50}$ secara berurutan sebesar 388, 225, 150, 98, dan 73 jsa. Hal tersebut menunjukkan bahwa semakin tinggi konsentrasi maka akan semakin rendah nilai $\mathrm{LT}_{50}$ nya.

Tabel 4. Lethal concentration $\left(\mathrm{LC}_{50}\right)$ ekstrak biji jarak pagar

\begin{tabular}{cc}
\hline JSA (jam) & $\mathrm{LC}_{50}(\mathrm{ppm})$ \\
\hline 24 & 29.913 \\
48 & 20.843 \\
72 & 11.132 \\
96 & 8.026 \\
120 & 2.639 \\
144 & 2.490 \\
\hline
\end{tabular}

Tabel 5. Lethal Time $\left(\mathrm{LT}_{50}\right)$ ekstrak biji jarak pagar

\begin{tabular}{cc}
\hline Konsentrasi (ppm) & $\mathrm{LT}_{50}(\mathrm{jsa})$ \\
\hline 625 & 388 \\
1.250 & 225 \\
2.500 & 150 \\
5.000 & 98 \\
10.000 & 73 \\
\hline
\end{tabular}

\section{KESIMPULAN}

Kesimpulan dari penelitian ini yaitu ekstrak bji jarak pagar fraksi $100 \% \mathrm{CHCl}_{3}$ pada konsentrasi 20.000 ppm menyebabkan mortalitas ulat Crocidolomia pavonana sebesar $100 \%$ pada pengamatan 24 jsa lebih tinggi daripada pada fraksi lainnya. Ekstrak biji jarak pagar dengan konsentrasi 20.000 ppm pada 24 jsa, 10.000 ppm pada 96 jsa, dan 5.000 ppm pada 120 jsa menyebabkan mortalitas ulat $C$. pavonana lebih dari $50 \%$. Namun pada perlakuan 20.000 ppm menyebabkan toksik bagi tanaman sehingga tidak dapat digunakan pada aplikasi lebih lanjut.

\section{DAFTAR PUSTAKA}

Adebowale, K.O. dan C.O. Adedire. 2006. Chemical composition and insecticidal properties of theunderutilized Jatropha seed oil. African J. of Biotechnology. 5(10): 901-906.

Carrillo, J. R., C. G. Jackson, T. D. Carrillo, dan J. Ellington. 1994. Evaluation of pesticide resistence in anaphes iole collected on five locations in the western united states. New Mexico State University Departement Of Entomologi, Plant Pathology, and Weed Science. Southwestern Entomologist. 19(2):1-4.

Evans, F. J. 1986. Naturally occurring phorbolesters. Boca Raton, FL: CRC Press, hlm: 171-215.

Kardinan, A. 2001. Pestisida Nabati, Ramuan dan Aplikasinya. Penebar Swadaya. Jakarta. $61 \mathrm{hlm}$.

Kodjo, T. A., M. Gbenonchi, A. Sadate, A. Komi, G. Y. M. Dieudonne, dan S. Komla. 2011. Bioinsectical effect of plant extracts and oil emulsions of $R$. Communis on the diamondback moth. Ecole Superieure Agronomie (ESA), universitas de Lome (UL), BP 1515 Lemo-Toge. Journal of Applied Biosciences. 43: 2899-2914.

Permadi, A. H., dan S. Sastrosiswojo. 1993. Kubis. Badan Penelitian dan Pengembangan Pertanian. Lembang.

Sayuthi M., Hasnah dan J. Saudahrul. 2014. Ekstrak daun pepaya dan biji jarak kepyar berpotensi sebagai Insektisida terhadap Hama Crocidolomia pavonana (lepidoptera: pyralidae) pada Tanaman Brokoli. J. Biologi Edukasi. Edisi 13. 6(2): 78-82. 
Tukimin, S.W., D. Soetopo, dan E. Karmawati. 2010. Pengaruh minyak jarak pagar (Jatropha curcas L.) terhadap mortalitas, berat pupa, dan peneluran hama jarak kepyar Achaea janata L. Jurnal Penelitian Tanaman Industri. 16(4): 159-164.

Uhan, T. S. 1993. Kehilangan hasil panen kubis karena ulat krop kubis (Crocidolomia binotalis Zeller) dan cara pengendaliannya. J.Hort. 3: 22-26.
Wina, E., I. W. R. Susana, dan T. Pasaribu. 2008. Pemanfaatan Bungkil Jarak Pagar (Jatropha Curcas) dan Kendalanya Sebagai Bahan Pakan Ternak. Wartazoa. 18(1): 1-8. 